\title{
Özel Öğrenci Yurtları Denetim Rehberinin Yasal Belgeler ve Alanyazın Temelinde Incelenmesi
}

\author{
Prof.Dr. Erdal Toprakçı \\ Ege Üniversitesi-Türkiye \\ erdal.toprakci@ege.edu.tr
}

\author{
Kübra Nur Özerten (Dok.Öğr.) \\ Ege Üniversitesi-Türkiye \\ knozerten@gmail.com
}

\begin{abstract}
Bu araştırmanın amacı, "Özel Öğrenci Yurtları Denetim Rehberini" yasal belgeler ile alanyazın temelinde incelemektir. Araştırmada nitel araştırma yaklaşımlarından doküman inceleme yöntemi kullanılmıştır. MEB Teftiş Kurulu Başkanlığı, 2016 ylında, Maarif Müfettişleri'nin teftiş sürecinde uygulayacakları esasları içeren ve çeşitli kurumların teftişi için hazırlanan 16 adet denetim rehberi yayımlamıştır. Çalışma dokümanl; yayımlanan rehberler arasında yer alan "Özel Öğrenci Yurt Rehberlik ve Denetim Rehberi"dir. Verilere, içerik analizi uygulanmıştır. Araştırmanın sonuçlarına göre; "Denetim Rehberinin Yasal Belgelerle ilişkisi" ve "Denetim Rehberinin Alanyazınla iliş̧kisi" olmak üzere iki tema ve bu temalardan "Denetim rehberinin yasal belgelerle tutarlıı̆ı" ve "Denetim rehberinin yasal belgelerle tutarsızlığı", "Denetim rehberinin alanyazınla tutarlıı̆ı", "Denetim rehberinin alanyazınla tutarsızlı̆̆ı" olmak üzere dört kategori ortaya çımıştır. Rehberin, yasal belgeler temelinde yarı yarıya tutarlı ve tutarsız olduğu söylenebilir. "Denetim rehberinin yasal belgelerle tutarsızlı̆ı" kategorisi altında; "Yasal belgeye göre güncel olmama", "Yasal belge belirsizliği", "Yasal boșluk", "ilgili yasal belgelere eksik gönderme", "Yasal belgeye göre eksik ifade edilme" kodları tespit edilmiştir. Bunun dışında, Rehber'in genel olarak alanyazınla tutarlı olduğu görülmüştür. Denetim rehberinin alanyazınla tutarsızlığı" kategorisi kapsamında; "I̧̧erik eksikliği", "Atıfsılık", "Kavram tutarsızlığı" ve "Aykırılık" kodları tespit edilmişdir. Uygulamacılara araştırmanın katkılarından yararlanmaları önerilirken, araştırmacılara, Özel Barınma Hizmetleri'nin Denetim Rehberi'ne bilimsel nitelik kazandıracak; nitel, nicel veya karma araştırma desenlerinde çalışmalar yapmaları önerilebilir.
\end{abstract}

Anahtar Kelimeler: Eğitim Denetimi, Yurt Denetimi, Denetim Rehberi, Özel Öğrenci Yurtları

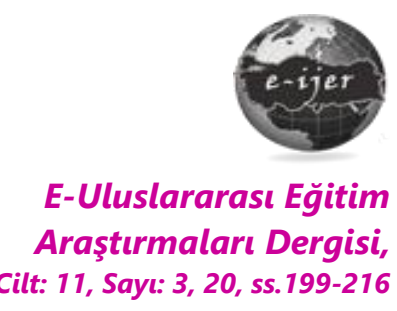

DOI: 10.19160/ijer.817509

\section{Önerilen Atıf}

Toprakçı, E. \&. Özerten, K.N. (2020). Özel Öğrenci Yurtları Denetim Rehberinin Yasal Belgeler ve Alanyazın Temelinde İncelenmesi, E-Uluslararası Eğitim Araştırmaları Dergisi, Cilt: 11, Sayı: 3, 2020, ss. 199-216, DOl: 10.19160/ijer.817509 


\section{GiRiş}

Birer hizmet üretmek için insanlar arası ilişkiler sonucu ortaya çıkan toplumsal kurumlar, yasal mevzuat temelinde belirlenen amaçlarını gerçekleştirmek üzere birtakım faaliyette bulunmaktadırlar. Temel toplumsal kurumlardan biri olan eğitim kurumları, bireylerin toplumsal yaşama hazırlanması amacıyla eğitim ve öğretim etkinliklerinin gerçekleştirildiği geniş bir sistemden oluşmaktadır. Eğitim kurumlarından toplumun intiyaçlarını, sosyal, ekonomik ve teknolojik değişimlerin gerektirdiği niteliklere göre karşılamaları beklenmektedir (Altunay, 2016). Bu bağlamda, içinde eğitim kurumlarının da olduğu yapının uyumu için kamusal yaşamın her alanında denetimin bir zorunluluk olduğu söylenebilir.

Denetim, belirlenen amaçlara yönelik örgütsel eylemlerin, eldeki madde ve insan kaynağına, kabul edilen ilke ve kurallara, ne derece uygun olduğunun anlaşılması sürecidir. Denetim temelde, örgütün amaçlarına ulaşma derecesini saptamayı, daha nitelikli sonuçlar elde edebilmek için önlem almayı ve süreci geliştirmeyi amaçlar. Denetim sistemi, örgütsel ve yönetimsel bir zorunluluk olarak her örgütte yer alır (Aydın, 1986). Denetim, bir süreç olarak; "durum saptama, değerlendirme, düzeltme ve geliştirme"aşamalarından oluşur (Başar, 2000). Buna göre denetimin nihai hedefinin geliştirme olduğu görülmektedir. Eğitsel etkinliklerin ve eğitim amaçlarına ulaşma durumlarının düzeltilmesi ve geliştirilmesi Eğitim Denetimi alanı ile gerçekleşmektedir. Geleneksel denetimde, kontrol ve değerlendirme süreçleri vurgulanırken, çağdaş eğitim anlayışı ile birlikte rehberlik ve geliştirme süreçleri de eğitim denetiminde ön plandadır (Beytekin ve Burak, 2019).

Eğitim denetimi, eğitim örgütlerinin amaçlarına ulaşma derecesini ortaya çıkarma, daha iyi sonuçlara ulaşabilmek için önlem alma ve süreci geliştirme çabalarının toplamıdır (Aydın, 2014). Eğitim denetimi süreci altı aşamadan oluşmaktadır (Toprakçı ve Akçay, 2016): 1) Denetlenecek olanın belirlenmesi. 2) Denetim öncesi hazırlıklar. 3) Gereken standartların belirlenmesi. 4) Denetim faaliyetinin gerçekleşmesi ile verilerin toplanması. 5) Toplanan verilerle daha önce belirlenen standartların karşılaştırıması. 6) Raporlaştırma. Eğitim denetiminin hedefi, eğitim ve öğretimin amaçlara en uygun değer ve işlemleri bulmasıdır (Bursalıoğlu, 2015). Eğitim örgütleri, ulaşılması istenen amaçların gerçekleştirilme durumunu sürekli olarak izlemek zorundadır. Bu durum, planlı ve devamlı olacak şekilde eğitimin girdilerinin, sürecin ve çıktılarının kontrol edilmesi ve değerlendirilmesi ile mümkündür (Yıldırım, 2009).

Eğitim denetiminin hizmet alanlarından biri olan ve bu araştırmanın da konusunu oluşturan Özel Öğrenci Yurtları (ÖÖY), öğrenciler için barınma hizmetleri sunan, eğitim ve öğretimi destekleyen bir eğitim kurumudur. Barınma hizmetleri; güvenlik ve sağlık intiyaçlarını gidermede olduğu gibi öğrencilerin kişisel, psikolojik ve sosyal gelişiminde de önemli rol oynamaktadır (Ayaz ve Başdağ, 2016). Maslow'un intiyaçlar Hiyerarşisi kuramına göre öğrenciler için yurtta kalmak, birinci basamaktaki fizyolojik intiyaçlar içerisinde görülebilir. Ayrıca barınma durumu, insanın, güvenlik ihtiyacının karşılanması ve sürdürülmesinde önemli rol oynamaktadır (Yüksel, 2018). Öğrenciler, barınma intiyaçlarını karşılamada seçenek olarak; ailelerinin ya da akrabalarının yanında, kamu ve özel yurtlarda, kiralık evlerde, apart otellerde, özel pansiyonlarda kalmayı değerlendirmektedirler (Filiz ve Çemrek, 2007). Anılan barınma yerlerinden biri olan yurt; öğrenciler için barınma, beslenme ve diğer sosyal gereksinimlerinin karşılandığı yer olarak görülmektedir. Özel yurtlar ise şahıslar tarafından kâr amacıyla açılan, öğrencilerin; barınma, beslenme, çalışma odası gibi ihtiyaçlarını gidermek için hizmet vermektedir. Özel yurtlar, sağladıkları hizmetlerle öğrencilere daha konforlu bir yaşam olanağı sunmanın yanı sıra güvenli olmaları sebebiyle de değerlendirilmektedir (Gökyer, 2012). Eğitim sürecinin bütünde daha nitelikli işlemesinde, hizmet ortamlarının; güvenli, sağlıklı ve yeterli olması ile birlikte, eğitsel amaçları gerçekleştirmeye elverişli, öğrencilerin akademik çalışmalarını güçlendirmeyi ve sosyal becerilerini geliştirmeyi destekleyecek donanımda düzenlenmiş olması da önemlidir (MEB, 2010). Bu bağlamda, eğitim etkinliklerinin sürekli olarak geliştirilmesi ve yenilenmesi gereken eylemler 
olduğu düşünüldüğünde, eğitim örgütlerindeki denetim çalışmalarına daha fazla önem verilmesi gerekmektedir (Yılmaz, 2009).

Dünyadaki örnekler incelendiğinde birçok ülkede (ABD, Fransa, Birleşik Krallık, Avustralya, Almanya) öğrencilerin barınma ihtiyaçlarına genellikle öğrenci yurtları ile çözüm üretildiği görülmektedir (TBMM, 2017). Türkiyedeki üniversiteler de olanakları bağlamında kendi bünyesinde var olan konukevi, yurt gibi birimlerle öğrencilerine barınma seçeneği sunmaktadır (Kara, 2009). Cumhuriyet Dönemi'nden sonra yükseköğrenim gören öğrencilerin sayılarındaki artış, öğrencilerin barınma gereksinimlerinin giderilmesinde bir sorun olarak ortaya çıkmıştır. Sonrasında belediyeler, il özel idareleri, çeşitli dernekler ve özel yurtlar açılmaya başlamış ve yurtların denetlenmesine yönelik birtakım yeni düzenlemeler getirilmiştir. 3 Mayıs 1949 tarihli Yükseköğretim Öğrenci Yurtları ve Aşevleri Kanunu ile Milli Eğitim Bakanlığı'na (MEB) yurt ve aşevlerinin sorumluluğu ve denetimi verilmiştir. Ayrıca anılan kanuna ek olarak çıkarılan 01.04.1950 tarihli ve 5661 sayılı kanun ile de MEB'in görev tanımlarınlarına, özel ve tüzel kişilere ait yurtların açılmasına izin verilmesi ve denetlenmesi de girmiştir (Kredi ve Yurtlar Genel Müdürlügü̈, 2020). MEB tarafından özel yurt, kamu yurtlarının dışındaki yurtlar olarak nitelendirilmektedir. Ancak özel öğrenci yurtları da kuruluş amacına göre; vakıf, dernek, ticari yurtlar olarak kategorilere ayrılmaktadır. Ticari yurtlar, şahıs veya şirketler tarafından kâr amacı gözeterek faaliyetlerde bulunmaktadır. Bu yurtlar, öğrencinin belirlenen ücreti ödemesi karşılığında hizmet sunmayı kabul etmektedir (Öztürk, 2014).

Anayasa'nın 42. Maddesi'nde "Eğitim ve öğretim, Atatürk ilkeleri ve inkılapları doğrultusunda, çağdaş bilim ve eğitim esaslarına göre Devlet'in gözetim ve denetimi altında yapılır."; 1739 Sayılı Millî Eğitim Temel Kanunu'nun 56. Maddesi'nde "Eğitim-öğretim hizmetinin, bu kanun hükümlerine göre Devlet adına yürütülmesinden, gözetim ve denetiminden MEB sorumludur." hükümleri yer almaktadır. Bu görev, 652 sayılı Kanun Hükmünde Kararname ile MEB Rehberlik ve Denetim Başkanlığı'nın sorumluluğundadır (MEB, 2016). Özel öğrenci barınma hizmeti veren kurumlar, Özel Öğretim Genel Müdürlüğü kapsamında yer almaktadır (MEB, 2018). MEB'e bağlı özel öğrenci yurtlarında, ayrıntılı denetim uygulanmakta ve bu yurtlar bulunduğu ilin, Il Milli Eğitim Müdürlüğü (MEM) tarafından denetlenmektedir (Özmen, 2019). Rehberlik ve Denetim Başkanlığı'na verilen görevlerin yerine getirilmesi amacıyla Teftiş Kurulu Başkanlığı (TKB); başkan, başkanlık birimlerinde ve çalışma merkezlerinde görevli bakanlık maarif müfettişi ve müfettiş yardımcılarından oluşmaktadır. MEB Teftiş Kurulu Başkanlığı Görev, Yetki, Sorumluluk ve Çalışma Esaslarına Dair Yönerge'nin 25. maddesine göre Rehberlik ve Denetim Daire Başkanlığı'nın görevlerinden birinin "Bakanlık merkez, taşra ve yurtdışı teşkilatı ile okul, kurum ve personelin rehberlik ve denetimine ilişkin esasların ve rehberlerin hazırlanması, uygulanması ve geliştirilmesine ilişkin iş ve işlemleri yürütmek" olduğu görülmektedir (MEB, 2017). Hazırlanan rehberlerden biri de, Özel Öğrenci Yurtları'nın denetiminde kullanılmak üzere hazırlanmıştır.

Özel öğrenci barınma hizmeti veren kurumlardaki süreçlerin izlenmesi, amaçlara ulaşmada engel oluşturan unsurların saptanması ve önlenmesi, sürekli iyileştirme ve geliştirmeye yönelik olumlu bir işleyiş gerçekleştirmenin yolu, eğitim denetimi ile mümkündür. Eğitim denetimi biliminin ürettiği bilgilerden yararlanmayan eğitimin denetim çabalarının, başarı sorunu ile karşılaşacağı söylenebilir (Toprakçı ve Akçay, 2016). 2016 yılında Adana'nın Aladağ ilçesinde ortaokul öğrencilerinin bulunduğu iki yüz kişilik özel bir yurtta, ortaya çıkan yangın kazası sonucunda, on bir kız öğrenci ve bir eğitimcinin hayatını kaybettiği, on altı kişinin ise yaralandığı tespit edilmiştir. Türkiye Büyük Millet Meclisi (TBMM) tarafından, ilgili olayda başta yönetim kurulu başkanı ve yurt müdürünün sorumlu oldukları ve yasal düzenlemelere uygun davranılmadığı yönünde 27.07.2017 tarihli 494 sayılı Meclis Araştırma Komisyon Raporu düzenlenmiştir. Bu raporda, söz konusu olayla ilgili denetim açığının olduğu net bir şekilde ortaya çıkarılmıştır (TBMM, 2017). Nitekim bu olaydan sonra değişen yönetmelikte (Resmi Gazete, 2017-a), "Öğrencilere yönelik barınma hizmeti verecek kurum binaları, her yıl öğretim yılı başlamadan önce yangın güvenliği, elektrik tesisat güvenliği, ısınma sistemi güvenliği, su ve gaz tesisatı güvenliği açısından ilgili kurum ve kuruluşlarca kontrol edilecek." ifadesi de yer almıştır. 
MEB'e bağı hizmet veren ve denetime tabi olan 4560 tane özel öğrenci yurdu bulunmaktadır (MEB, 2018). Bu yurtların denetimi, Teftiş Kurulu Başkanlığı tarafından oluşturulan "Özel Öğrenci Yurdu Denetim Rehberi" (bu çalışma boyunca "denetim rehberi" ya da "rehber" kelimeleri yurtlar için hazırlanmış bu rehberi ifade etmektedir) ile belli standartlara ve izlenceye oturtulmuştur. Rehberin hem denetmenlere hem de bu kurumlarda görevli yönetici ve ilgili sorumlu kişilere yol haritası çizdiği; hangi konularda denetleneceklerine ilişkin bilgi verdiği söylenebilir (Resmi Gazete, 2017-a). Rehberin, mevzuata dayanmasının ve değişen mevzuatla güncelliğini korumasının kullanıc dostu olarak nitelik kazanmasına, denetimde ilgili kişilerin en az eksik ve hata ile süreci yürütmelerine olanak sağladığı düşünülebilir. "Sosyal bilimlerin yasaları anladığımız anlamda, bireyler, toplumlar ve insanlar arası ilişkileri düzenleyen 'yasalar' olmak zorundadır. Yani, ülkeleri yöneten meclisler ya da ilgililer, çıkaracakları yasaları (yasal belgeleri) sosyal bilimin ürettiği bilgilerden yola çıkarak oluştururlarsa sosyal bilimin de fen bilimleri gibi 'yasaları' olmuş olacaktır" (Toprakçı, 2017). Rehberin, Eğitim Denetimi biliminin ortaya koyduğu bilimsel veriler ışığında hazırlanmasının, rehberin geçerliliğini artırmada önemli bir gösterge olduğu açıktır. Ayrıca rehberin bilimsel nitelik kazanması ile denetsel faaliyetlerde, uygulayıcıların denetim kavramlarına ilişkin 'kavram yanılgı'sını önlemede de etkili olabileceği düşünülmektedir.

$\mathrm{Bu}$ araştırmanın amacl; yasal belgeler ve alanyazın temelinde Özel Öğrenci Yurtları Rehberlik ve Denetim Rehberi' nin incelenmesidir. Çalışma boyunca bu rehber "denetim rehberi" olarak anılmıştır. Alanyazında Özel Öğrenci Barınma Hizmetleri ile ilgili çalışmaların büyük bir çoğunluğunun öğrenci kaynaklı ve yönetim sorunlarını konu edindiği görülmektedir (Öksüz, 2012; Ok ve Girgin, 2015; Ayaz ve Başdağ, 2016; Met ve Özdemir, 2016; Aktaş,2017; Yüksel 2018, Uysal ve Yorulmaz, 2019). Bu bağlamda alanyazında (Eğitim Denetimi), özel öğrenci yurtlarının denetimine yönelik bir çalışmaya rastlanmadığı gibi Özel Öğrenci Yurt Denetim Rehberi ile ilgili bir çalışmaya da rastlanmamıştır. Nitekim bilimin kültür haline gelmiş olduğu toplumlarda, bilimsel bilginin, yasaları etkileme ve belirleme işlevi yaygın olmakla birlikte ülkemizde bu kültürün çok zayıf olduğunu söyleyebiliriz. Bu temelde söz konusu özel öğrenci yurtlarının denetim rehberinde de bu özellik aranabilmelidir. Rehberin alanyazın temelinde bilimsel bilgi ile donanık olması, nitelikli bir denetsel faaliyetin gerçekleşebileceğinin göstergesidir. Rehberin yasal belge ve alanyazın temelinde tutarlı ve tutarsız yönlerinin incelenmesinin gerek uygulayıcılara yol göstermesi gerekse alanyazındaki bu eksikliği gidermesi açısından önemli olduğu düşünülmektedir.

\section{YÖNTEM}

Araştırma modeli: : Araştırmada nitel araştırma yaklaşımlarından doküman inceleme yöntemi kullanılmıştır. Araştırmada veriler, nitel araştırmaya dayalı belge (doküman) incelemesi tekniği kullanılarak elde edilmiştir. Doküman incelemesi araştırmalarda, araştırmanın amacının gerçekleştirilmesinde kullanılan genel yaklaşım veya veri toplama tekniği olarak iki şekilde ifade edilmektedir. Bowen'a (2009) göre, doküman incelemesinin analitik aşamaları; "dokümanlarda yer alan verilerin bulunması, seçilmesi, değerlendirilmesi (anlamlandırıması) ve sentezlenmesi"dir (Akt.: Özkan, 2019). Doküman incelemesi, ele alınan dokümanın içeriğinin analizini belirli bir zamanın, dönemin veya bağlamın içerisinde dokümanda iletilmek istenen niyetin, düşüncenin incelenmesini içerir (Harwey, 2018: Akt. Özkan, 2019). Doküman incelemesi kişisel belgelerde kullanıldığı gibi, kamu ve arşiv belgeleri için de kullanılabilir. Kamu dokümanları, kurumların olay ya da süreçlerin göstergesi olarak düşünülebilir.

Çalışma Grubu: MEB Teftiş Kurulu Başkanlığı, 2016 yılında, maarif müfettişlerinin teftiş sürecinde uygulayacakları esasları içeren ve çeşitli kurumların teftişi için hazırlanan 16 adet denetim rehberi yayımlamıştır. Çalışma dokümanı; yayımlanan rehberler arasında yer alan "Özel Öğrenci Yurt Rehberlik ve Denetim Rehberi"dir. Ayrıca, eğitim denetimi alanına ilişkin çalışmalar ve yasal 
belgelere ulaşmada çevrim içi ortam (Google Akademik, Mevzuat - resmi siteleri, Yöktez) ile araştırmacıların gerçek ve sanal kütüphanesinde bulunan kaynaklardan yararlanılmıştır. Buna göre, ulaşılan belgeler (rehber hariç olmak üzere) sınırlığında bir inceleme gerçekleşmiştir. Özel Öğrenci Yurt Denetim Rehberi, MEB Teftiş Kurulu Başkanlığı'nın internet sitesinden (tkb.meb.gov.tr), "Yayınlarımı" sayfasından 28.04.2020 tarihinde bilgisayar ortamına indirilerek edinilmiştir. Rehberde bahsi geçen ilgili kanun, yönetmelik, yönerge, genelge ve diğer belgelere yine bakanlığın kendi sitesinden ulaşılmış ve orijinalliği teyit edilmiştir.

Verilerin Analizi: Araştırmada veriler, içerik analizi türlerinden 'kategorisel analiz' kullanılmıştır. Kategorisel analiz, genel olarak belirli bir mesajın önce birimlere (kodlara) bölünmesi ve ardından bu kodların kategoriler ve temalar halinde gruplandırılmasıdır (Miles ve Huberman, 2016). (Yıldırım ve Şimşek, 2016). Bu analizde verilerin mutlaka nicelleştirilmesi gerekmeyebilir ancak veriler, yüzde dağılımı ya da sayısallaştırma yoluyla da verilebilir.

Tablo1. Rehberin yasal belgeler ve alanyazın temelinde analizi ile ilgili analiz örnekleri

\begin{tabular}{|c|c|c|c|}
\hline Tema & Kategori & Kodlar & Temayla ilişkili ífadeler \& Gönderme yapılan yasal belge/ ilgili madde \\
\hline \multirow{4}{*}{ 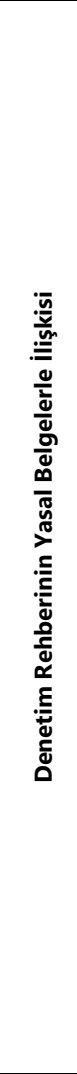 } & \multirow{2}{*}{ 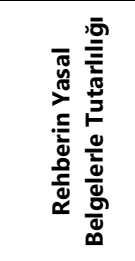 } & \multirow[t]{2}{*}{ 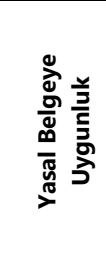 } & $\begin{array}{l}\text { Rehberde: Yönetici ve etüt odaları ile diğer birimlerin ihtiyacı karşılama durumu (Özel } \\
\text { Öğrenci Yurtları Yönetmeliği (ÖÖYY) (2004)-Md.6/c-1,2,3,4,5) } \\
\text { Yasal belgedeki karşılığı: Madde 6. c) Yurt binasında;1) Yönetici odası,2) Personel odası,3) } \\
\text { Orta öğretim yurtlarında belletici odası,4) Ziyaretçi odası veya tahsisli bölümü, 5) Her bir } \\
\text { öğrenci için en az 1/2 metrekare alanı olan, yurt yatak kapasitesinin en az 1/5'i oranında } \\
\text { etüt/ççış̧ma odası (ÖÖYY, Md.6/c-1,2,3,4,5) }\end{array}$ \\
\hline & & & $\begin{array}{l}\text { Rehberin kaynak gösterdiği yasal belgeye ulaşılmış ve ifadenin yasal belgeyle örtüşmesi } \\
\text { durumunda ortaya çıkan kod "Yasal belgeye uygunluk" kodu olarak tanımlanmıştır. }\end{array}$ \\
\hline & \multirow[t]{2}{*}{ 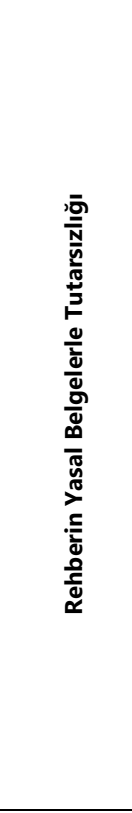 } & \multirow[t]{2}{*}{ 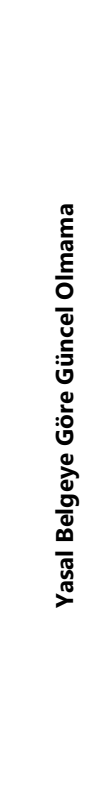 } & $\begin{array}{l}\text { Rehberde: Gerekli yazışmaların yapılması, dosyalanması ve evrak arşivlenme durumu (Özel } \\
\text { Öğrenci Yurtları Yönetmeliği-Md.15) } \\
\text { ÖörY (2004): Madde } 15-\text { Yurtlarda aşağıdaki belgelerin bulundurulması ve kayıtların } \\
\text { tutulması zorunludur. a) Öğrenci kayıt defteri veya dosyası,b) Orta öğretim yurtlarında kitaplık } \\
\text { defteri,c) Öğrenci dosyaları ve yoklama defterleri,d) Öğrenci disiplin kurulu karar defteri,e) } \\
\text { Geçici barınanlara ilişkin kayıt defteri veya dosyası, f) Gelen-giden evrak ve zimmet defterleri, } \\
\text { g) Revir defteri, h) Yurt personeli dosyaları ve sözleşmeleri, l) Yazışma dosyaları, j) Ücretli } \\
\text { yurtlar için, } 213 \text { sayılı Vergi Usul Kanunu ile diğer mali mevzuatın öngördüğ̈̈ defter ve } \\
\text { belgeler, k) Yemekli yurtlar için tabela, l) Nöbet defteri, m) Denetim defteri } \\
\text { ÖörY (2017): Madde 21- (1) Kurumlarda e-Barınma modülünde kayıtlı bilgilerin dışında } \\
\text { aşağıdaki defterler ile belgelerin bulundurulması ve kayıtların tutulması zorunludur. (1) a) } \\
\text { Öğrenci yoklama defteri. b) Öğrenci disiplin kurulu karar defteri. c) Gelen ve giden evrak ve } \\
\text { zimmet defterleri. ç) Revir defteri.d) Kurum personeli dosyaları ve sözleşmeleri.e) Yazışma } \\
\text { dosyaları. f) Aylık yemek listesi. g) Nöbet defteri. ğ) Ziyaretçi defteri. h) Öğrenci veya öğrencinin } \\
\text { velisi ile kurum arasında yapılan taahhütname dosyası. l) Denetim defteri. (2) Birinci fıkrada } \\
\text { belirtilen defterler sayfa numaraları verilerek il veya ilçe millî eğitim müdürlüklerince } \\
\text { onaylanır. (1) 3) Kurumlarda kayıt, ücret takibi, yoklama ve benzeri işlemler ayrıca e-Barınma } \\
\text { modülüne işlenir. (4) 4/1/1961 tarihli ve } 213 \text { sayılı Vergi Usul Kanunu hükümleri ile diğer mali } \\
\text { mevzuat düzenlemeleri saklıdır. }\end{array}$ \\
\hline & & & $\begin{array}{l}\text { Rehberdeki ilgili madde } 15 \text { incelendiğinde, gönderme yapılan Özel öğrenci yurtları } \\
\text { yönetmeliği'nin, Bakanlar kurulu kararıyla } 2004 \text { yılında çıkarıldığı, bu yönetmelikte } 2009 \text { ile } \\
2011 \text { yılında bazı değişiklikler yapıldığı görülmüştür. Sonraki yıllarda anılan bu yönetmelik } \\
\text { yürürlükten kaldırılmış, 6/5/2017 tarihli } 30058 \text { sayılı Resmi Gazete'de yayımlanarak "Özel } \\
\text { Öğrenci Barınma Hizmetleri Yönetmeliği" şeklinde yürürlüğe konulmuştur. Buna göre ilgili } \\
\text { ifade, güncellenen yönetmeliğin 21. Maddesinde birkısım değişiklikle geçmektedir. }\end{array}$ \\
\hline \multirow{4}{*}{ 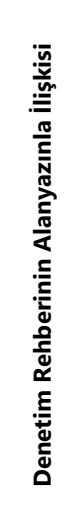 } & \multirow[t]{2}{*}{ 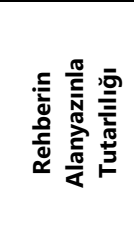 } & \multirow[t]{2}{*}{ 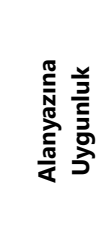 } & $\begin{array}{l}\text { Rehberde: Rehberlik ve Denetim Araçlarının Belirlenmesi-Maarif müfettişi, rehberlik ve } \\
\text { sırasında gerekli gördüğü uygun denetim araçlarını (gözlem, görüşme, belge inceleme vb.) } \\
\text { kullanabilir. } \\
\text { Alanyazın: Denetlenenle ilgili; bireysel veya grupla mülakat, odak grup görüşmeleri, gözlem, } \\
\text { rapor inceleme, etkinlik kayıtları vb. çoklu veri kaynakları ile çok gerekli veriler elde edilebilir } \\
\text { (Aydın, 2014). }\end{array}$ \\
\hline & & & Rehberin alanyazına uygun olduğu bu kod ile ilişkilendirilmiştir. \\
\hline & \multirow{2}{*}{ 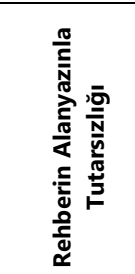 } & \multirow{2}{*}{ 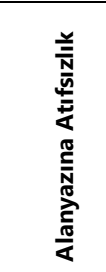 } & 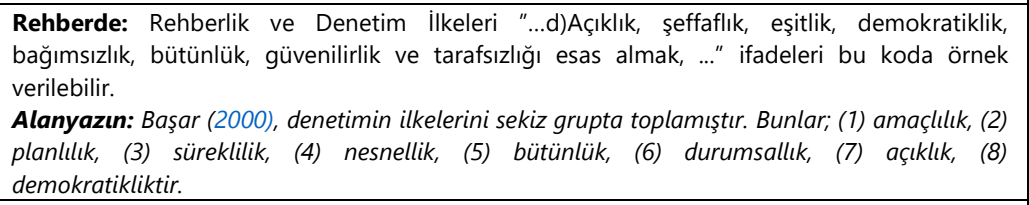 \\
\hline & & & Bu koda ilişkin, verilen örnekte olduğu gibi alanyazına atıfta bulunulmadığı görülmektedir. \\
\hline
\end{tabular}


Verilerin analizi aşamasında, araştırmacılar tarafından öncelikle rehber ve gönderme yaptığı yasal belgeler incelenmiştir. Rehberin alanyazın ile ilişkisinin analiz işleminde araştırmacılar, rehberi; çevrim içi ortam, gerçek ve sanal kütüphaneleri yardımcı araçları ile "alanyazınsal zihin çerçeveleri" (uzmanlıkları) sınırlığında aşkınlık seviyesine (anlamaya odaklanan üst düzey düşünüş performansı) gelinceye kadar okuyarak kod, kategori ve temalara ulaşmışlardır. Söz konusu Rehberin alanyazın ile ilişkisi, çalışmayı yapanların kaynakları ile "alanyazınsal zihin çerçeveleri" (uzmanlıkları) sınırlıı̆ındadır. Son olarak veriyi kullanma aşamasında, belirlenen temalara göre uygun olan alıntılarla analiz desteklenmiş ve yorumlanmıştır. Araştırmada temalar; "Denetim Rehberinin Yasal Belgelerle ilişkisi", "Denetim Rehberinin Alanyazınla ilişkisi" olarak biçimlenirken, "Denetim Rehberinin Yasal Belgelerle Tutarlıı̆y Tutarsızlığı", "Denetim Rehberinin Alanyazınla Tutarlı̆ğ/ Tutarsızlığı" şeklinde kategoriler oluşmuş, ayrı ayrı olmak üzere onların altında da yasal belge için; "Yasal belgeye uygunluk", "Yasal belgeye göre güncel olmama", "Yasal belge belirsizliği", "Yasal belge boşluğu", "ilgili yasal belgelere eksik gönderme", "Yasal belgeye göre eksik ifade edilme", alanyazın için ise; "Uygunluk", "içerik eksikliği", "Atıfsızlı", "Kavram tutarsızlığı" ve "Aykırılık" şeklinde kodlar ortaya çıkmıştır. Verilerin bulguya dönüşmesinde anlaşılmayı kuvvetlendirmek için verilerin yüzde dağılımı ya da sayısallaştırma yoluna da gidilmiştir. Yapılan içerik analiz örneği Tablo1'de verilmektedir.

Tablo1'de görüldüğü gibi veriler analiz edilmiştir. Ayrıca, rehberdeki bazı ifadeler, içerik veya ilgili yasal belge temelinde kapsamlı olmasından kaynaklı birden fazla kategori altında yer alabilmiştir. Yani bu durumda ilgili ifade, her kategorinin altında ayrı ayrı değerlendirilmiş olup madde sayısallaştırmasında da ilişkili olduğu her temada yeniden kullanılıışırı.

Geçerlik ve Güvenirlik: Nitel araştırmalarda geçerlik ve güvenirliğin sağlanabilmesi için bazı önlemler alınmaktadır. Bunun için uzman görüşü ve meslektaş teyidi gibi çeşitli stratejiler kullanılmaktadır. Meslektaş teyidi, elde edilen verilerin karşılaştııımasıyla araştırma sürecine eleştirel gözle bakan ve araştırmacıya geribildirimde bulunan uzman görüşünü ifade etmektedir (Yıldırım ve Şimşek, 2016). Araştırmanın geçerliğinin sağlanması için öncelikle meslektaş teyidine gidilmiştir. Bu amaçla MEB Teftiş Kurulu Başkanlığı'nın farklı kurumlara yönelik rehberlik ve denetim rehberlerini inceleyen araştırmacılar düzenli aralıklarla bir araya gelmiştir. İnternet ortamında her hafta belirlenen gün ve saatte canlı toplantı araçları üzerinden toplantılar düzenlenmiş ve tekrar izlenebilmesi için bu toplantılar kaydedilmiştir. Toplantılarda öncelikle rehberlerin hangi yönlerden incelenebileceğine ilişkin tartışmalar gerçekleştirilmiştir. Ardından araştırmacılar inceleyecekleri rehberlere yönelik içerik analizi yaparak temaları, kategori ve kodları oluşturmuştur. Oluşturulan temalar, kategori ve kodlar karşılaştııılarak benzer ve farklı yönler üzerinde durulmuştur. Anlaşmazlığa düşülen noktalar tartışılmış ve fikir birliğine ulaşılıncaya dek toplantılar devam etmiştir. Ayrıca uzman görüşü için denetim alanında yetkin ve yayımları olan bir akademisyen ile bir maarif müfettişi bu toplantılarda yer alarak toplantı süresince geri bildirimlerde bulunmuşlardır. Diğer araştırmacılar talep etmeleri dahilinde veya gelecekte başka bir araştırmada karşılaştırma yapılmak üzere araştırmanın ham verileri saklanmıştır. Böylece dış güvenilirlik (teyit edilebilirlik) arttırılmaya çalışılmıştır.

\section{BULGULAR VE YORUM}

Bu çalışmada elde edilen bulgular, yasal belgeler ve alanyazın temelinde, Özel Öğrenci Yurtları Denetim Rehberi'ne uygulanan içerik analizi sonucunda ortaya çıkan tema, kategori ve kodlardan oluşmuştur. Bulguları destekleyen alıntılara ve bu bulguların yorumlanmasına da yer verilmiştir. Rehbere ilişkin yapılmış bir çalışmaya rastlanmadığı için bulgular, alanyazındaki çalışmaların benzer ve farklı yönleri açısından karşılaş̧ııılarak yorumlanamamıştır. 


\section{Denetim Rehberinin Yasal Belgelerle ilişkisi}

Aşağıda yer alan Tablo 2'de "Denetim rehberinin yasal belgelerle ilişkisi teması" altında "Denetim rehberinin yasal belgelerle tutarlıı̆ı" ve "Denetim rehberinin yasal belgelerle tutarsızlığı" kategorileri ve kodlarının dağılımları gösterilmiştir.

Tablo2. "Denetim rehberinin yasal belgelerle ilişkisi" teması altında ortaya çıkan kategori ve kodların dağılımı

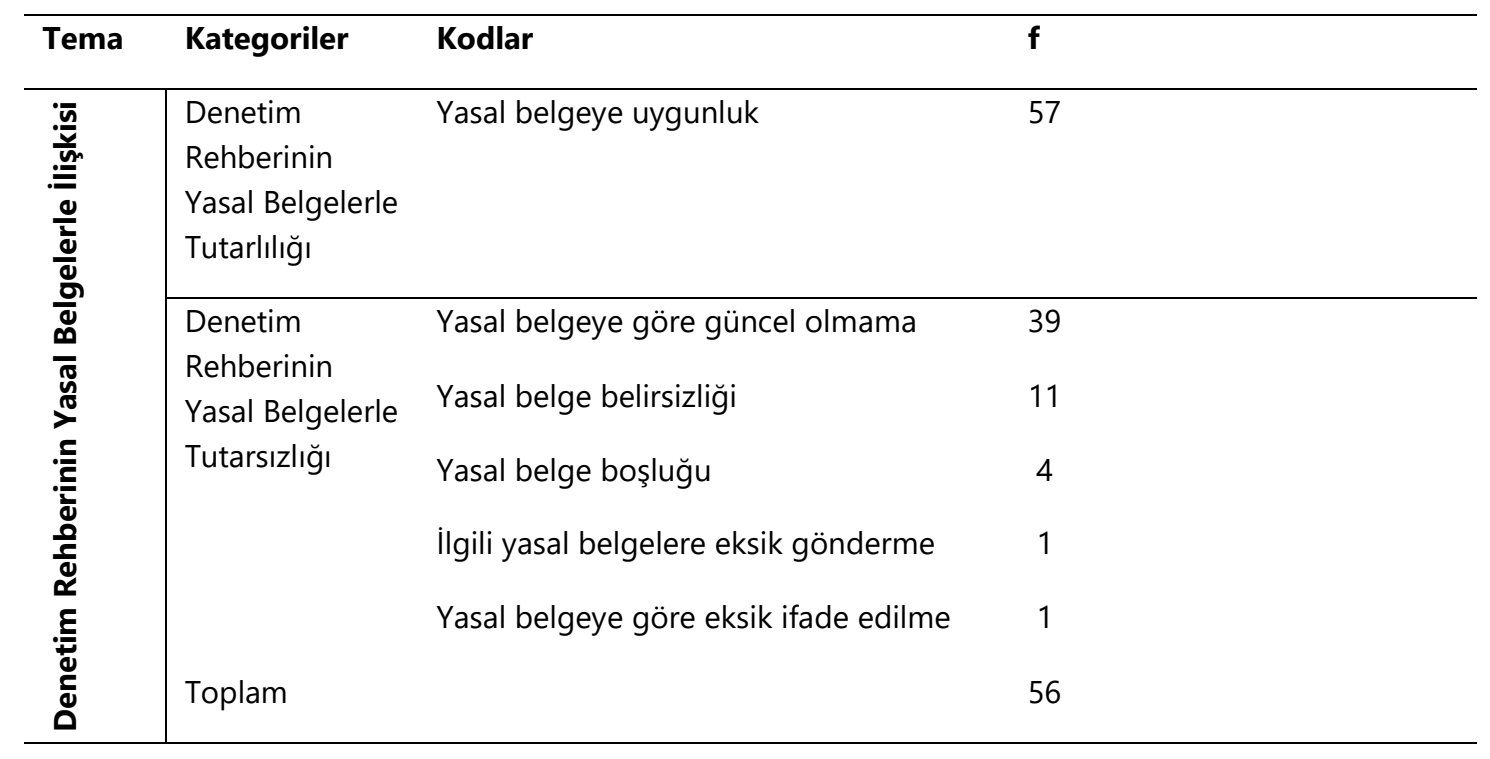

Tablo 2'de görüldüğü gibi "Denetim rehberinin yasal belgelerle tutarlı̆̆ı" ve "Denetim rehberinin yasal belgelerle tutarsızlığı" olmak üzere iki kategorinin ortaya çıktığı görülmektedir. "Denetim rehberinin yasal belgelerle tutarlıı̆ı $(n=57)$ " kategorisi altında "Yasal belgeye uygunluk" kodu; "Denetim rehberinin yasal belgelerle tutarsızlı̆ı $(n=56)$ " kategorisi altında "Yasal belgeye göre güncel olmama" ( $n=39)$, "Yasal belge belirsizliği" ( $n=11)$, "Yasal boşluk" ( $n=4)$, "ilgili yasal belgelere eksik gönderme" ( $n=1)$, "Yasal belgeye göre eksik ifade edilme" ( $n=1)$ kodları tespit edilmiştir.

\subsection{Denetim Rehberinin Yasal Belgelerle Tutarlılığı}

"Denetim rehberinin yasal belgelerle tutarlı̆ı̆ı" $(\mathrm{n}=57)$ kategorisi altında "Yasal belgeyle uygunluk" $(\mathrm{n}=57)$ olarak bir tane kod tespit edilmiştir. "Denetim rehberinin yasal belgelerle tutarlıığının" "Yasal belgeye uygunluk" kodu, rehberdeki kısım ile yasal belgeye ilişkin gönderme örtüşüyorsa veya ikisi birbiriyle doğru şekilde ilişkilendirilmişse tercih edilmiştir. "Tutarlılık" kategorisinden "Yasal belgeye uygunluk" koduna ilişkin bir örnek alıntı şöyledir:

"Belletici öğretmenin görevlerini yerine getirme durumu (Özel Öğrenci Yurtları Yönetmeliği- Md.30)". Gönderme yapılan ilgili yönetmeliğin 30. maddesi ise şu şekildedir: "Belleticilerin görevleri şunlardır: a) Yurtta kalan öğrencilerin etüt saatlerinde eğitimleri ile ilgilenmek, b) Yemekhane ve yatakhanelerde öğrencilere rehberlik ederek düzenli bir şekilde yemek yemelerini ve yatıp kalkmalarını sağlamak, c) Çamaşır ve banyo işlerinin zamanında ve düzenli olarak yerine getirilmesini sağlamak, d) Etütlerde yoklama yapmak, e) Hastalanan ögrencilerin durumunu yöneticilere bildirmek, f) Önemli disiplin olaylarında durumu yurt müdürüne zamanında bildirmek, g) Müdürün vereceği diğer görevleri yapmak". Görüldüğü üzere, rehberdeki kısım ile gönderme yapılan yasal belgenin ilgili maddesi doğru bir şekilde ilişkilendirildiğinden bu ifade "Denetim rehberinin yasal belgelerle tutarlı̆̆ı" kategorisinin "Yasal belgeyle uygunluk $(n=57)$ " kodu altında incelenmiştir. Genel olarak rehberin, denetime referans oluşturan yasal belgelerle tutarlı olması beklenen bir durumdur. 


\subsection{Denetim Rehberinin Yasal Belgelerle Tutarsızlığı}

"Denetim rehberinin yasal belgelerle tutarsızlığı $(n=56)$ " kategorisinin "Yasal belgeye göre güncel olmama" ( $n=39)$, "Yasal belge belirsizliği" $(n=11)$, "Yasal boşluk" $(n=4)$, "ilgili yasal dayanaklara eksik gönderme" ( $n=1)$, "Yasal belgeye göre eksik ifade edilme" $(n=1)$ kodlarında ifadelere rastlanmıştır.

"Yasal belgeye göre güncel olmama" ( $n=39)$ kodu, rehberdeki ifadenin ya da bu ifadenin yanında yer alan yasal belgenin güncel olmadığı ya da yürürlükten kaldııılığı durumda tercih edilmiştir. Söz konusu koda ilişkin ifadelerin oldukça fazla sayıda göze çarpmasının nedeni, rehberin 2016 yılında hazırlanması ve sonrasında güncellenmemesi olabilir.

Rehberdeki "Yönetim Faaliyetleri" bölümünün "Atama" alt başlığında yer alan "Kurum müdürü, müdür yardımcısı, belletmen ve diğer personelin öğrenim durumları ve diğer niteliklerinin mevzuat hükümlerine uygunluğu (Özel Ögrenci Yurtları Yönetmeliği-Md.26; Geçici Md.1, 657 Sayılı Memurları Kanunu Md.48)" ifadesi bu kod kapsamında bir örnek olarak gösterilebilir. Denetim rehberinden yapılan bu alıntı incelendiğinde, 03.11.2004 tarihli ve 2004/8106 sayılı Bakanlar Kurulu Kararıyla çıkarılan ve 06.05.2017 tarihine kadar yürürlükte kalan Özel Öğrenci Yurtları Yönetmeliği'ne atıfta bulunduğu; Madde 26 - Yurtlarda görevlendirilen personelde, 657 sayılı Devlet Memurları Kanunu'nun 48 inci maddesindeki genel şartlara ilave olarak; "... b) Belleticilik için yüksekögrrenim mezunu olmak şartı aranır ve ögretmenlik yapmış olanlar tercih edilir. Belleticiler, orta ögretim yurtlarında görevlendirilir. Yükseköğretim yurtlarında ise belletici görevlendirilmesi yapılmaz. Yurtlarda belletici sayısı, ihtiyaca göre yurt yönetimince belirlenir." ilgili ifadeler yer alırken, 06.05.2017 tarihli ve 30058 sayılı Resmi Gazete'de (2017-a) yayımlanarak yürürlüğe giren Özel Öğrenci Barınma Hizmetleri Yönetmeliği'nde ise "Madde 28(1) Ortaokul, imam-hatip ortaokulu ve ortaöğretim kurumları öğrencilerine yönelik hizmet veren kurumlarda elli (elli dâhil) ögrenciye kadar bir, yüz (yüz dâhil) ögrenciye kadar iki, yüzden fazla öğrenci için en az üç belletici görevlendirilir. Belleticiler, öğretmen olma şartlarını taşıyanlar öncelikli olmak üzere yükseköğretim mezunu olanlar arasından görevlendirilir. (Ek cümle: 22/1/2018-2018/11277 K.) Belletici olma şartlarını haiz olan müdür yardımcıları ve yönetim memurları da istemeleri halinde belletici olarak görevlendirilebilir. Ayrıca, ortaokul ve imam-hatip ortaokulu ögrencilerine yönelik hizmet veren kurumlarda en az bir, ortaöğretim kurumları öğrencilerine yönelik hizmet veren kurumlarda ise isteğe bağlı olarak rehber öğretmen görevlendirilir. Rehber ögretmen olarak atanacaklarda Bakanlıkça belirlenen şartlar aranır." hükmü yer almıştır. Bu bağlamda güncel yönetmelikle (2017-a), barınma hizmetlerinin ilköğretim düzeyi (ortaokul, imamhatip ortaokulu) için de verildiği, belletmen sayısının nicelik olarak açıkça belirtildiği ve rehber öğretmen görevlendirilmesi şartının güncel yönetmelikle getirildiği görülmektedir.

Bir başka örnek ise, barınma hizmeti veren yurtların yangın riskine karşın gerekli önlemleri alması noktasında detaylı maddelere güncel yönetmelikte yer verildiği görülmektedir. Rehberin atıfta bulunduğu Özel Öğrenci Yurtları Yönetmeliği'ne (Resmi Gazete, 2004-a) göre; "Kurum binalarındaki yangın güvenliği, elektrik tesisat güvenliği, ısınma sistemi güvenliği, su ve gaz tesisat güvenliği" hususlarında kontrol şartı yokken, güncel yönetmelik olan Özel Öğrenci Barınma Hizmetleri Yönetmeliği (Resmi Gazete, 2017-a), "Kurum binalarının, her yıl öğretim yılı başlamadan önce yangın güvenliği, elektrik tesisat güvenliği, ısınma sistemi güvenliği, su ve gaz tesisatı güvenliği hususlarında itfaiye, üniversitelerin ilgili bölümleri, mühendis odaları veya diğer ilgili kurum veya kuruluşlara kurum yönetimince kontrol ettirilme" şartı getirilmiştir. Anılan eski yönetmelikte "Kurum binalarında ahşap giydirme kullanılamaz." şartı yokken, güncel yönetmelikte "Kurum binalarının iç ve dış duvarlar ile tavan döşemelerinde ahşap ve yanma özelliği yüksek malzemelerden yapılmış giydirmeler kullanılamaz." hükmü getirilmiştir. Eski yönetmelikte "Yangın çıkış kapısına" ilişkin şartlar aranmazken, güncel yönetmelikte "Yangın 
merdivenleri ve kaçış yollarının kapıları yangına karşı dayanıklı malzemeden yapılır. Acil çıkış kapıları dışardan açılamayan ancak içeriden kilitlenemeyen veya yangın ikazıyla otomatik olarak açılacak şekilde yapılır." hükümleri getirilmiştir. Eski yönetmelikte "Kurum binasında yangın ikazı ve otomatik söndürme sistemi" şartı yer almazken, yeni yönetmelikte "Kurum binalarında yangın ikaz amacıyla duman ve ısıya duyarlı, gaz kaçaklarını algılayan sensörler, alarm sistemi ile kurum kontenjanının 100'den fazla olması halinde otomatik söndürme sisteminin bulunması" şartı getirilmistir. Eski yönetmelikte "Kurumda acil durum tatbikatı" şartı yer almazken, yeni yönetmelikte "Kuruma kaydolan her ögrenciye kurum yönetimi veya belletici tarafından kurum binası tanıtılır, acil durumlar için tahliye yolları ile toplanma yerleri gösterilir. Kurumlarda, kurum personelinin ve ögrencilerin katıldı̆̆ acil durum tahliye uygulaması her yıl ögretim yılının başladığı ilk hafta ile ikinci yarıyılın ilk haftası içinde olmak üzere yılda iki kez yapılır ve tutanakla kayıt altına alınır" hükmü getirilmiştir. Söz konusu mevzuat değişikliğinin Adana'nın Aladağ İlçesinde bulunan Kız Öğrenci Yurdu'nda meydana gelen yangın kazasının bir benzerinin yaşanmaması adına ve kamusal eğitim ve barınma haklarının tüm öğrenciler için güvence altına alınıp yaygınlaştırı ması için gereken tedbirlerin belirlenmesi açısından olduğu söylenebilir. Bu bağlamda Denetim Rehberi'nin mevzuat alanındaki değişiklikler dikkate alınarak yeniden hazırlanması gerektiği açıkça görülmektedir.

"Yasal belge belirsizliği" ( $n=11)$ kodu, rehberde ilgili konuya ilişkin yasal belgeye açıkça gönderme yapılmadığı durumlar tespit edildiğinde kullanılmıştır. Bir örnek vermek gerekirse; rehberdeki "Mali İ̧ ve İşlemler" bölümünün "Çalışan İşlemleri" kısmında yer alan "2) Aylık ücret miktarının her yıl belirlenen asgari ücretin altında olamayacağı hususunun sağlanma durumu" ifadesi, Asgari Ücret Yönetmeliği'ne (Resmi Gazete,2004-b) mad.12 "İsverenin Sorumluluğu: iş̧̧ilere, Komisyonca belirlenen ücretlerden düşük ücret ödenemez. Işs sözleşmelerine ve toplu iş sözleşmelerine bunun aksine hükümler konulamaz." açıkça gönderme yapmamaktadır. Bir başka örnek ise rehberin; Defter, belge tutuma ve arşivleme bölümünde "4)E-yurt modülü için gerekli olan bilgilerin zamanında il/ilçe milli eğitim müdürlüğüne iletilme durum" ifadesi Özel Öğrenci Yurtları Yönetmeliği (Resmi Gazete, 2004-a) Madde 28'in c bendine “- Yurt müdürünün görevleri: ilgili mercilerce yurt hakkında istenen bilgilerin ve belgelerin doğru bir şekilde ve zamanında gönderilmesini sağlamak." açıkça atıf yapmamaktadır. Nitekim anılan bu ifadelerin yasal belge temelinde rehberde gösterilmesi, rehberin uygulayıcılar tarafından daha çok dikkate alınmasında etkili olabileceği şeklinde yorumlanabilir.

"Yasal boşluk $(n=4)$ " kodu rehberde yer alan içeriğe yönelik herhangi bir yasal belge yoksa tercih edilmiştir. Rehberden bir örnek göstermek gerekirse, Çözüm Önerileri başlığında yer alan "Bakanlığa, il / ilçe Milli Eğitim Müdürlüğü'ne, kuruma yönelik olarak; kurumun gelişimine katkı sağlayacak, değer katacak, geleceğe ilişkin bir vizyon oluşturacak, aynı zamanda gerçekçi ve uygulanabilir önerilere yer verilmelidir." ifadesine yönelik hiçbir yasal belgede açık bir hükme rastlanmamıştır.

En az ifadeye rastlanan kodlardan biri "ilgili yasal belgelere eksik gönderme" ( $n=1)$ kodu, rehberde gönderme yapılan ilgili belgede başka maddelere de atıf yapılması gerekiyorsa araştırmalar esnasında gönderme yapılan yasal belgeler dışında başka destekleyici belgelere de ulaşıldıysa fakat bunlara rehberde değinilmediyse tercih edilmiştir. Rehberde, "Kurumun Temizliği ve Sağlık Hizmetleri" bölümünde "Yemekli yurtlarda gıda malzemelerinin kontrolünün muayene komisyonu tarafından yapılmasl; yemek menülerinde mevsimler ve ögrencilerin gelişim özelliklerinin dikkate alınması ile miktar, gramaj, kalori hesabı ve kalite bakımından sağlık şartlarına uygun olarak hazırlanmasının sağlanması durumu (Özel Öğrenci Yurtları YönetmeliğiMd.47,48)" ifadesinin gönderme yaptığı yasal belgeyi, "Gıda güvenliği ve kalitesinin denetimi ve kontrolüne dair yönetmeliğin (Resmi Gazete,2008) desteklediği görülmüştür. Anılan yönetmelik Mad.12-h,l,i,j,k,l bendleri ile gıda malzemelerinin kontrolünde gerçekleşmesi gereken denetim süreçlerine gönderme yapmaktadır. Rehberin, ilgili ifadelere yeteri kadar yer vermesinin, uygulamalarda gerekli önlemin sağlanması açısından yol gösterici niteliğini artırabilir. 
En az ifadeye rastlanan bir başka kod ise "Yasal belgeye göre eksik ifade edilmedir ( $n=1)$." Bu kod kapsamında, rehberin tanımlar bölümünde; "Denetim, Rehberlik, Rehberlik ve Denetim Bilgi Ișlem Sistemi, Denetim Emri, Grup Sorumlusu, Rehberlik ve Denetim Öncesi Hazırlık Toplantısı, Çalıșma Planı, Bilgi Notu (Föy), Değerlendirme Toplantısı, Rapor, Raportör, Gelișim Planı" gibi kavramlar yer alırken, yasal belgede olan "Yurt", "Yurt yönetimi", "Ögrretim yılı", "Ders yllı", "Veli veya vasi" kavram tanımlarının rehberde verilmediği görülmektedir. Bu kavramlara yönelik tanımlar, Özel Öğrenci Yurt Yönetmeliği'nin (Resmi Gazete, 2004-a) 4. Maddesinin $b, c, d$, e ve $f$ bendlerinde yer almaktadır. "... b) Yurt: Orta öğrenim veya yükseköğrenim öğrencilerinin barınma, beslenme ve diğer sosyal ihtiyaçlarının karşılandığı yeri, c) Yurt yönetimi: Yurt müdürü, müdür yardımcısı ve yönetim memurundan meydana gelen oluşumu, d) Öğretim yılı: Ders yılının başladığı tarihten itibaren, ertesi ders yılının başladığı tarihe kadar geçen süreyi, e) Ders yılı: Derslerin başladığı tarihten, derslerin kesildiği tarihe kadar geçen ve iki dönemi içine alan süreyi, f) Veli veya vasi: Ana/babası veya yasal olarak öğrencinin sorumluluğunu üstlenen kișiyi ifade eder." Bu eksikliğin bir nedeni rehberin hazırlanışında mevzuattan derinlemesine yararlanılmaması olabilir.

\section{2- Denetim Rehberinin Alanyazınla ilişkisi}

Aşağıda yer alan Tablo 3'te, "Denetim rehberinin alanyazınla ilişkisi teması" altında "Denetim rehberinin alanyazınla tutarlılı̆ı" ve "Denetim rehberinin alanyazınla tutarsızlığı" kategorileri ile kodları verilmiştir. Bu kısımda denetim rehberi ya da yurtların denetimi ile ilgili doğrudan bir alanyazın çalışmasının yokluğundan kaynaklı dolaylı çalışmalar temelinde hareket edildiğinden sayısallaştırmaya gidilmemiştir.

\subsection{Denetim Rehberinin Alanyazınla Tutarlılığı}

Yapılan analizler sonucunda, rehberin genel olarak alanyazınla tutarlı olduğu görülmüştür. Denetim rehberinin hazırlanmasında, alanyazının bir hareket noktası olarak dikkate alınmasının rehbere açıklık kazandırması açısından önemli olduğu söylenebilir. Bu bağlamda, rehberin "Öğrenci" bölümünün "Sosyal faaliyetler" alt başlığında yer alan "Orta öğrenim yurtlarında öğrencilerin fikri, ruhi ve bedeni gelişmelerini sağlayabilmeleri amacıyla her türlü imkân araştırılarak sportif, kültürel ve sosyal çalışmalara katılmalarının sağlanma durumu (Özel Öğrenci Yurtları Yönetmeliği-Md.46)" ifadesi "Denetim rehberinin alanyazınla tutarlı̈ı̆ı" temasının "Uygunluk" koduna bir örnek olarak verilebilir. Denetim, öğrenmeyi daha etkili kılmak amacıyla kurumun işleyişini, öğretme sürecini doğrudan etkileyecek biçimde düzenlemektir. Eğitim ve barınma yerleri, kütüphaneler, sosyal ve kültürel tesisler gibi her türlü eğitim ortamının öğrencilerin ruhsal, bedensel ve bilişsel gelişimine destek olması, nitelikli denetim faaliyetlerinin yürütülmesi ile mümkündür (Köklü, 1996). Bu bağlamda, rehberin alanyazın ile tutarlığı olduğu söylenebilir.

\subsection{Denetim Rehberinin Alanyazınla Tutarsızlığı}

Denetim rehberinin incelenmesi sonucu alanyazınla tutarsı olan noktalar tespit edilmiştir. Buna göre Tablo 3'te analiz sonucu ortaya çıkan tema, kategori ve kodlar verilmiştir.

Tablo 3'te görüldüğü gibi, "Denetim rehberinin alanyazınla ilişkisi" temasının "Denetim rehberinin alanyazınla tutarsızlığı" kategorisi kapsamında "içerik eksikliğı", "Atıfsızlık", "Kavram tutarsızlı̆ı" ve "Aykırılık" olmak üzere dört kod tespit edilmiştir.

"Denetim rehberinin alanyazınla tutarsızlığı" kategorisinin "içerik eksikliğı" kodu, rehberde yer almayan fakat alanyazında olan durumlar tespit edildiğinde kullanulmıştır. Rehberin "Rehberlik ve Denetim Araçlarının Belirlenmesi" bölümünde yer alan açıklama, "Maarif müfettişi, rehberlik ve denetimler sırasında gerekli gördüğü uygun denetim araçlarını (gözlem, görüşme, belge inceleme vb.) geliştirerek kullanabilir." ifadesidir. Denetimin en temel öğesi, gözlemdir. Eğitim denetimi alanyazını temel alınarak örnek vermek gerekirse, Goldhammer ve arkadaşları 
(1980) denetimi, (1) Gözlem öncesi görüşme, (2) Gözlem, (3) Analiz, (4) Denetim görüşmesi (gözlem sonrası görüşme), (5) Görüşme sonrası analizden oluşan bir süreç olarak ele almaktadırlar (Akt.: Köklü, 1996). Rehberde, denetim kuramlarının (bilimsel, sanatsal, kliniksel, farklılaştırılmış, öğretimsel, gelişimsel) bulgularından biri olan gözlem aşamasına, denetim sürecinin bir parçası olarak ayrıntılı yer verilmediği görülmüştür. Söz konusu bu durum, Türkiye'de müfettiş yetiştirmede, "Eğitim Denetimi'nin" ayrı bir uzmanlık alanı olduğu fikrinin yerleşmemesinden kaynaklı olduğu söylenebilir.

Tablo3. "Denetim rehberinin alanyazınla ilişkisi" teması altında ortaya çıkan kategori ve kodların dağılımı

\begin{tabular}{|c|c|c|}
\hline Tema & Kategoriler & Kodlar \\
\hline \multirow[b]{2}{*}{ 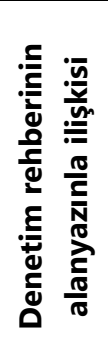 } & Denetim rehberinin alanyazınla tutarlılı̆ı & Uygunluk \\
\hline & Denetim rehberinin alanyazınla tutarsızlığı & $\begin{array}{l}\text { İçerik eksikliği } \\
\text { Atıfıızıı } \\
\text { Kavram tutarsızlığı } \\
\text { Aykırııı }\end{array}$ \\
\hline
\end{tabular}

"Atıfsızlı" kodu, alanyazınla ister tutarlı ister tutarsız olsun rehberin konusu ile ilgili yapılmış bilimsel çalışmalara gönderme yapmama durumunu ifade etmektedir. Rehberin hiçbir yerinde alanyazındaki herhangi bir araştırmaya, kitaba, çalışmaya atıf yoktur. Bu bulgunun elde edilmesi, rehberin sadece mevzuat odaklı hazırlanarak bilimsel bilginin göz ardı edilmesi şeklinde açıklanabilir. Diğer yandan rehberin var olan haliyle alanyazınla tutarlı çıkan yanları itibariyle o kısımların gönderme yaptığı mevzuatın şekillenişi ya da oluşturulması esnasında bilimsel bilgiden hareket edilmiş olabileceğine ilişkin bir ipucu da verebilir. Zaten, eğitbilimciler eğitim pratiğinin teorilerini hazırladıklarında, bu teoriler üretildiği toplumun ve belki de uluslararası toplumun gerçekten (hukuksal anlamda) yasal belgelerine yansıdığında ancak (o ülkede ya da dünyada) eğitimin bilimliliğinden söz edilebilir (Toprakçı, 2017; Toprakçı, Dağdeviren, Oflaz ve Türe 2010). Eğitim denetimi akademisyenlerinin ürettiği bilginin işlerliği açısından uygulamadakilerin onların çalışmalarından atıf yaparak yararlanmaları, hem uygulamaya nitelik kazandırmak hem de akademisyeni takdir etmek bağlamlı katkı sağlayıcı olabilir. Bu koda ilişkin, denetim rehberinin bütününde, alanyazına hiç atıfta bulunulmadığı görülmektedir. Denetimin amaçlarına ulaşabilmesi için gözetilmesi gereken ilkelerden biri, nesnellik ilkesidir. Nesnel olmayan bir denetimin, işlevlerini yerine getirilebilmesinin güç olduğu söylenebilir. Denetim sürecinde bilimsel bulgulardan yararlanmak, nesnel ölçütler kullanmak gerekir. Eğitim kurumlarında rehberlik ve denetim etkinliklerinde dikkate alınması gereken ilkelerden biri; bilimsel ve objektif esaslara dayalı olmasıdır (Resmi Gazete, 2017-b). Nitekim rehberde; denetim rehberinin kapsam ve sınırlıı̆ı bölümünde bu koda ilişkin "Bu denetim rehberi hazırlanırken, MEB Rehberlik ve Denetim Başkanlığı ile Maarif Müfettişleri Başkanlıkları Yönetmeliği'nde belirtilen denetim hizmetlerinin çeşitleri referans alınmıştır. Bu rehberle maarif müfettişlerine denetimlerde yol göstermek, kurum denetiminde uygulama birliği sağlamak ve sorunlu alanların önceliklendirilerek denetim yapılmasını gerçekleştirmek amaçlanmıştır. Rehber, kurumların işleyişi ile ilgili yasal düzenlemeleri kaldırmaz, kısıtlamaz ve sınırlandırmaz. Denetim sırasında kurumların özelliğine göre ortaya çıkabilecek özel durumlar, kurumun şartlarından kaynaklanabilecek ve rehberde öngörülemeyen istisnai hususların ortaya çıkması halleri denetimin dışında bırakılamaz. Denetimlerde yürürlükteki hukuki düzenlemeler dikkate alınacaktır. Ayrıca denetim rehberinde yer almayan hususlar için ilgili mevzuat hükümlerine göre rehberlik ve denetim yapılacaktır. Rehberde yer alan mevzuat atıfları bilgi amaçlıdır." ifadesi örnek gösterilebilir. Denetim rehberinin teorik olarak, "Eğitim kurumlarının yürüttükleri faaliyetleri ölçmek ve değerlendirmek üzere geliştirilmiş 
bir ölçme aracı" (Kubalı, 1999) olduğu düşünülebilir. Bu bağlamda, rehberin sadece mevzuat temelinde hazırlanmış olması, denetim rehberinin geçerliği ve güvenirliğini sorgulatmaktadır.

"Kavram tutarsızlığı" kodu, alanyazın ve rehberdeki kavramların kullanımının tutarsız olduğu ya da birbirini kapsayan kavramlar tespit edildiğinde tercih edilmiştir. Bu bağlamda rehberde, "Rehberlik ve denetim ilkeleri" bölümünde "tarafsızlığı esas almak" ve "objektif olmak" gibi kavramların birlikte kullanıldığı görülmüştür. Ayrıca rehberde, "Maarif Müfettişlerinin Görevleri" bölümünde, "...b) Rehberlik, denetim, inceleme, soruşturma çalışmaları neticesinde düzenleyecekleri raporları en geç yirmi gün, kapsamlı işlerde ise verilen ek süre içinde tamamlamak" ifadesi de bu kodla ilişkilendirilmektedir. Nitekim, ifadede geçen "denetim" kavramı, çağdaş denetim anlayışında; inceleme, araştırma, soruşturma ve rehberlik hizmetlerini kapsamaktadır. Bu bağlamda, rehberin sadece yasal mevzuat temelinde hazırlanması, söz konusu kavram yanılgılarına sebep olarak gösterilebilir.

"Aykırllk" kodu, denetim rehberinde alanyazınla çelişen ve düzeltilmesi gereken bir durum varsa tercih edilmiştir. Rehberde Sorunlar başlığı altında "Sorunlar tespit edilirken; mevzuat, üst politika belgeleri (Kalkınma Planı, Hükümet Programı, Millı̂ Eğitim Bakanlığı Stratejik Planı) ile kurumun stratejik planında ortaya konulmuş amaç ve hedefler göz önünde bulundurulur." ifadesi bu kod kapsamında düşünülebilir. Sorunları tespit etmede Eğitim Denetimi alanyazınına başvurma konusunun göz ardı edildiği açıkça görülmektedir. Çağdaş eğitim denetiminin amacı, öğrenme ve öğretmede önemli rol oynayan tüm öğeleri birlikte ele alıp, süreci izlemek, değerlendirmek ve geliştirmek üzere gerekli önlemleri almaktır (Beycioğlu ve Dönmez, 2009). Özel öğrenci yurtlarının sorunlarını tespit etmede, Eğitim denetimi alanyazınından yararlanılması, öğrencilerin öğrenme yaşantılarını desteklemek amacıyla yurt kaynaklarının kolektif olarak etkili bir biçimde kullanılması, değerlendirilmesi ve geliştirmesi olarak düşünülebilir.

\section{SONUÇ VE ÖNERILER}

Araştırmanın bu bölümünde, sonuçlara, bulgular temelinde yer verilmiştir. Sonuçların altında, araştırmacı ve uygulayıcılar için öneriler getirilmeye çalışılmıştır.

- Rehberin, yasal belgelerle ilişki temelinde tutarlııklar tespit edilmiştir. Denetim rehberinin hazırlanma amaçlarından birinin; Bakanlık okul ve kurumlarına, özel öğretim kurumlarına, gerçek ve tüzel kişilere rehberlik etmek olduğu düşünüldüğünde; Rehberin yasal belgeler temelinde tutarlıı̆ııın devamı konusunda uygulayıcılar için takip, inceleme ve raporlama görevlerini üstlenmek üzere bir komisyon kurulması önerilebilir. Araştırmacılar, denetim rehberinin yasal belgeler temelinde tutarlılı̆ının devamını sağlamada yasal dayanakları içeriksel ve biçimsel olarak inceleyebilir.

- Rehberin, yasal belgelerle ilişki temelinde tutarsızlıkları olduğu tespit edilmiştir. Rehberde gönderme yapılan yasal belgelerin bir kısmının güncel olmadığı belirlenmiştir. Bu bağlamda denetim rehberinin revize edilmesi önem arz etmektedir. Denetleyen ve denetlenenlerin yılda en az bir kere bir araya gelerek rehberlik ve denetimin etkili ve verimli bir şekilde yürütülmesine katkı sağlayacak güncelleme çalışmaları içerisinde katkı sunmaları önerilebilir. Güncellenen yasal belgeler temelinde değişiklik yapılan ilgili maddelerin, denetim rehberinde dijital zincir blokları ile bağlantılı şekilde (link olarak veya QR kodları ile) yer almasına yönelik araştırmacılar tarafından çalışmalar yapılabilir. Rehberdeki bazı ifadelerde, ilgili yasal belgeye gönderme yapılmadığı (yasal belge belirsizliği) görülmüştür. Denetim hizmetlerinin tutarlılığının ve yasal gereksinimlere uyumun sağlanması için uygulayıcıların mevzuattaki gelişmeleri takip etmeleri önerilebilir. Araştırmacılara ise gönderme yapılmayan maddelerin gerekçelerini araştıran çalışmalar yapmaları önerilebilir. Rehberde yer alan bazı ifadelerin yasal dayanağının olmadığı (yasal boşluk) tespit edilmiştir. Rehberde yasal dayanağa yer verilmesi, uygulayıcıların sorumluluğunu hukuki delil bağlamında pekiştirmesi bakımından önemli 
görülmektedir. Ayrıca uygulayıcılar arasında eylem birliğini sağlama açısından da rehberdeki ifadelerin yasal zeminde oluşturulmasına özen gösterilmesi önerilebilir. Uygulayıcılar, ilgili rehberin ve hazırlanan diğer benzer rehberlerin içeriğinin bir yasal arka plana sahip olup olmadığını denetleyecek yetkinlikte birimler nasıl oluşturulabileceğine ilişkin çalışmalar yapabilir. Araştırmacılara, rehberin içeriğini oluşturan yasal dayanakların hangi yöntemlerle denetlenebileceği konusunda araştırmalar yapmaları önerilebilir. Rehberdeki bazı ifadelerde yasal dayanaklara eksik gönderme yapıldığı belirlenmiştir. Yasal belgelere eksik veya yetersiz gönderme yapılmasının, rehberin ilgili kurumda meydana gelebilecek olası denetim açıklarına zemin hazırladığı düşünülebilir. Bu bağlamda, maarif müfettişlerinin özel bir yurda gittiği zaman nelere bakacağının rehberde ayrıntılı şekilde tanımlanması; denetim hedeflerini gerçekleştirmede yeterli ve güvenilir bilgi ve dokümanları tespit etmede kolaylık sağlaması bakımından önemli görülmektedir. Maarif müfettiş yardımcılarının yeterliliklerine ilişkin değerlendirilmelerinde, ağılıklı sınav konu alanları, mevzuat bilgisidir. Müfettişlere, mevzuat temelinde mesleki bilgi ve becerilerini artırma ve değişen mevzuatın takibini araştırma alışkanlığı kazandırmak amaçlı hizmetiçi eğitimler düzenlenebilir. Araştırmacılara ise özel yurtlarda meydana gelen kazalarla (örneğin, yangın, gıda zehirlenmesi vb.) ilgili olası denetim açıklarına yönelik, maarif müfettişlerinden oluşan çalışma grupları ile araştırma yapmaları önerilebilir.

- Rehberin genel olarak alanyazınla tutarlı olduğu görülmüştür. Rehberin alanyazın temelinde tutarlıı̆ııı sağlamada, uygulayıcıların Eğitim Denetimi biliminin ortaya koyduğu bilimsel çalışmaları takip etmeleri önerilebilir. Araştırmacıların ise, denetim rehberinin alanyazın temelinde tutarlıığının devamı için uygulayıcılar ile eylem birliği içersinde olacak çalışmalar; projeler yapmaları önerilebilir.

- Rehberin, alanyazınla ilişki temelinde tutarsızııları olduğu tespit edilmiştir. Rehberdeki bazı ifadelerin içeriğinde alanyazına göre içerik eksiklikleri olduğu görülmüştür. Bu bağlamda, denetim rehberinin hazırlık aşamasında akademisyenlerin, uzmanların görev alması veya inceleyip görüş sunmalarının sağlanması, alanyazın temelinde tutarlılığını sağlamada etkili olabilir. Araştırmacıların özel barınma hizmetlerine yönelik çalışmalar yapmaları, bu yolla rehberde hizmet alanlarının intiyaçlarına yönelik daha gerçekçi düzenlemeler hazırlanabilmesi için veri sağlamaları önerilebilir. Rehberdeki ifadelerin hiçbirinde bilimsel çalışmalara gönderme yapılmadığı (atıfsızık) belirlenmiştir. MEB'e bağı birçok denetim rehberinin bu konuda benzerliğinin yüksek düzeyde olması, denetim rehberlerinin hızlıca, çalakalem fakat kanun ve yönetmeliklere uygun olarak hazırlama çabasının genelinde yapılmaya çalışıımasından olduğu izlenimi vermektedir. Denetimden beklenen etkili sonuçlara ulaşmak, kullanılan ölçme aracının geçerli ve güvenilir olmasına bağııdır. Bu doğrultuda, uygulayııılar için, maarif müfettişlerine hizmet içi eğitim programlarının bilimsel çalışmalar temelinde düzenlemeleri tavsiye edilebilir. Uygulayıcıların bu konuda yetkinliğinin artııımasına yönelik olarak farkındalık merkezli çeşitli eğitim ve destek hizmetlerinin verilmesi önerilebilir. Araştırmacılara ise özel barınma hizmetlerinin denetim rehberine bilimsel nitelik kazandıracak; nitel, nicel veya karma araştırma desenlerinde çalışmalar yapmaları önerilebilir. Rehberdeki kavramların bir kısmının kullanımının alanyazınla tutarsız olduğu ya da birbirini kapsayan kavramlar (kavram tutarsızlığı) kullanıldığı tespit edilmiştir. Taslak aşamasında olan denetim rehberinin son halinin, alanyazın temelinde, bilim uzmanlarından oluşan bir ekip aracılığı ile kontrol edilmesi uygulayıcılara tavsiye edilebilir. Araştırmacıların, değişen bilimsel ve teknolojik gelişmeler doğrultusunda denetim türlerini, denetim boyutlarını ve denetim kuramlarını temel alan araştırmalar yapmaları önerilebilir. Rehberde alanyazınla çelişen ve düzeltilmesi gereken ifadeler (aykırılık) olduğu görülmüştür. Maarif müfettişlerine, Eğitim Yönetimi alanında lisansüstü eğitim alma koşulu, atama veya yetiştirilme süreçlerine getirilebilir. Bu bağlamda, maarif 
müfettişlerinin mesleki gelişimlerine katkı sağlayacak bu koşula yönelik, teşvik edici yasal düzenlemelerin yapılması uygulayııılara önerilebilir. Araştırmacılara, alanyazında denetim rehberi ile ilgili benzer sorunların yaşandığı ülkelerde çözüm için izlenen alternatif süreçlerin neler olabileceği konusunda incelemeler yapılması önerilebilir.

\section{KAYNAKÇA}

Aktaş, E. (2017). Yurtlarda kullanıcı gereksinimleri ve mersin kı öğrenci yurdu örneğinde incelenmesi. (Yayımlanmamış yüksek lisans tezi). Yakın Doğu Üniversitesi, Lefkoşa.

Altunay, E. (2016). Eğitbilim Pedandragoji. E. Toprakçı, (Ed.) Eğitimin Denetimi, Ankara: Ütopya Yayınevi. Ayaz, N., \& Başdağ, S. (2016). Hizmet satın alma davranışı: üniversite öğrencilerinin özel yurt seçimleri. Kastamonu University Journal of Economics \& Administrative Sciences Faculty, 13.

Aydın, M. (1986). Çağdaş eğitim denetimi. IM Eğitim Araş̧ırma Yayın Danışmanlık.

Aydın, i. (2014). Öğretimde denetim (5.bs.). Ankara: Pegem Akademi

Başar, H. (2000). Eğitim Denetçisi. Ankara: Pegem A Yayıncılık.

Beycioğlu, K., \& Dönmez, B. (2009). Eğitim denetimini yeniden düşünmek. Inönü Üniversitesi Eğitim Fakültesi Dergisi, 10(2), 71-93.

Beytekin, O. F., \& Burak, A. (2019). Öğretmenlerinin öğretimsel denetim uygulamalarına ilişkin metaforik algılarının incelenmesi. Turan: Stratejik Araştırmalar Merkezi, 11(44), 325-335.

Bursalığlu, Z. (2015). Okul yönetiminde yeni yapı ve davranış, Ankara: Pegem A Yayıncılık.

Filiz, Z., Çemrek, F. (2007). Üniversite öğrencilerinin barınma sorunlarının uygunluk analizi ile incelenmesi. Eskişehir Osmangazi Üniversitesi Sosyal Bilimler Dergisi, 8(2), 207-224.

Gökyer, N. (2012). Özel Öğrenci Yurtlarında Kalan Öğrencilerin Yurt Yönetiminden Kaynaklanan Sorunlara Iliş̧kin Görüşleri (Elazığ ili Örneği). International Journal of Social Science, 5(4), 75-94.

Kara, Ö. (2009). Yükseköğrenimde barınma sorunu: Türkiye'de öğrenci yurtları ve dünyadan örnekler. (Yayınlanmamış yüksek lisans tezi). Akdeniz Üniversitesi Sosyal Bilimler Enstitüsü, Antalya.

Kredi ve Yurtlar Müdürlüğü [KYGM] (2020). https://kygm.gsb.gov.tr/Sayfalar/2397/3193/Tarihce, Erişim tarihi 20.05.2020

Kubalı, D. (1999). Performans denetimi. Amme Idaresi Dergisi, 35(1), 31-62.

Köklü, M. (1996). Etkili denetim. Kuram ve Uygulamada Egitim Yönetimi Dergisi, 2(2), 259-268.

Met, Ö., \& Özdemir, i. M. (2016). Gözardı Edilen Bir İşletme Türü Olarak Üniversite Öğrenci Yurtlarının Profili. Journal of Alanya Faculty of Business/Alanya Isletme Fakültesi Dergisi, 8(1).

Miles, B. M., \& Huberman, M. A., (2016). Nitel Veri Analizi (S. Akbaba., A. Ersoy Çev.) Ankara: Pegem Akademi.

Milli Eğitim Bakanlığı [MEB] (2010). Özel Öğrenci Yurtları Rehberlik ve Denetim Rehberi.

Milli Eğitim Bakanlığı [MEB] (2016). Özel Öğrenci Yurtları Rehberlik ve Denetim Rehberi, https://tkb.meb.gov.tr/www/yayinlarimiz/icerik/13, Erişim tarihi 15.05.2020

Milli Eğitim Bakanlığı [MEB] (2017). https://tkb.meb.gov.tr/meb_iys_dosyalar/2018_07/04160948_yonerge.pdf. Erişim tarihi 20.05 .2020

Milli Eğitim Bakanlı̆̆ı [MEB] (2018). https://ookgm.meb.gov.tr, Erişim tarihi 20.05.2020

Ok, M. A., \& Girgin, F. M. (2015). Ankara'da iki özel yurt işletmesinde SERVQUAL yöntemi ile hizmet kalitesinin ölçülmesi. Yönetim Bilimleri Dergisi, 13(25), 295-323.

Öksüz, E. (2012). Yüksek ögrrenim kredi ve yurtlar kurumu ile özel yurtlarda ikamet eden öğrencilerin boş zaman faaliyetlerinin değerlendirilmesi (Balıkesir Ili Örneği) (Yayınlanmamış Yüksek Lisans Tezi), Balıkesir Üniversitesi Sosyal Bilimler Enstitüsü, Balıkesir.

Özkan, U.B. (2019). Eğitim bilimleri araştırmaları için doküman inceleme yöntemi. Ankara: Pegem Akademi

Özmen, C. (2019). Üniversite ögrenci yurtlarının hizmet kalite algısının ölçülmesi: karabük ili yurtlarında bir uygulama. (Yayınlanmamış yüksek lisans tezi). Karabük Üniversitesi, Karabük.

Öztürk, K. (2014). Tarihi Süreciyle Yurt Hizmetleri ve Önemi. Eğitim-Öğretim Bilim Araştırma Dergisi, 30.

Resmi Gazete (2004-a). Özel Öğrenci Yurtları Yönetmeliği, https://www.resmigazete.gov.tr/eskiler/2004/12/20041203.htm\#9, Erişim tarihi 19.05 .2020

Resmi Gazete (2004-b). Asgari Ücret Yönetmeliği, https://www.resmigazete.gov.tr/eskiler/2004/08/20040801.htm, Erişim tarihi 20.06.2020

Resmi Gazete (2008). Gıda Güvenliği ve Kalitesinin Denetimi ve Kontrolüne Dair Yönetmelik. https://www.resmigazete.gov.tr/eskiler/2008/09/20080926-4.htm, Erişim tarihi 20.06.2020

Resmi Gazete (2017-a). Özel Öğrenci Barınma Hizmetleri Yönetmeliği, https://www.resmigazete.gov.tr/eskiler/2017/05/20170506-5.pdf, Erişim tarihi 19.05.2020 
Resmi Gazete (2017-b). Milli Eğitim Bakanlığı Teftiş Kurulu Yönetmeliği, https://www.resmigazete.gov.tr/eskiler/2017/08/20170820-1.htm, Erişim tarihi 19.05.2020

Toprakçı, E. (2017). Sınıf Yönetimi (3.bs.). Ankara: Pegem Akademi.

Toprakçı, E., \& Akçay, A. (2016). Türkiye'de Kamu Yararına Çalışan Derneklerin Egitim Faaliyetlerinin Yönetimi ve Denetimi (Yasal Belgeler Temelinde Nitel Bir Analiz). Cumhuriyet International Journal of Education, 5(1), 29.

Toprakçı, E., Dağdeviren, İ., Oflaz, G. ve Türe E. (2010). Eğitim fakülteleri öğretim elemanlarının bilim anlayışları temelinde eğitimin bilimliliği, Bilim ve Ütopya Dergisi, 10(190), 45-56

Türkiye Büyük Millet Meclisi [TBMM, 2017]. Meclis araştırması komisyon raporu https://www.tbmm.gov.tr/develop/owa/sirasayi_sd.sorgu_baslangic. Erişim tarihi 02.06.2020

Uysal, B., \& Yorulmaz, M. (2019). Özel yurt öğrencilerinin başarı yönelimlerinin belirlenmesi üzerine bir araştırma . Uluslararası Sağlık Bilimleri ve Yönetimi Kongresi e-Bildiri Kitabı, Üsküdar Üniversitesi, İstanbul.

Yıldırım, N. (2009). Denetim sürecinde ilköğretim okul müdürlerinin değerlendirilme formu üzerine değerlendirme. Sosyal Bilimler Araştırmaları Dergisi, 4(2), 199-212.

Yıldırım, A., Şimşek, H. (2016). Nitel Araştırma Yöntemleri. (10.bs.). İstanbul: Seçkin Yayınları.

Yılmaz, K. (2009). Okul müdürlerinin denetim görevi. Inönü Üniversitesi Eğitim Fakültesi Dergisi 10(1).

Yüksel, S. K. (2018). Özel yüksek öğretim öğrenci yurtlarında hizmet kalitesi kapsamında öğrenci memnuniyetinin değerlendirilmesi: Balıkesir örneği (Yayımlanmamış Yüksek Lisans Tezi). Balıkesir Üniversitesi, Balıkesir. 


\section{The Examination of the Supervisory Guideline of Private Student Dormitories Based on Legal Documents and the Literature}

\author{
Prof.Dr. Erdal Toprakçı \\ Ege University-Turkey \\ erdal.toprakci@ege.edu.tr
}

\author{
Kübra Nur Özerten(Ph.D.Stud.) \\ Ege University-Turkey \\ knozerten@gmail.com
}

\begin{abstract}
The purpose of this research is to examine the "The Supervisory Guideline of Private Student Dormitories" on the basis of the legal documents and literature. In this research, 'document review method', which is a qualitative research approach was used. The data were obtained using the document examination technique. Content analysis was applied to the data. According to the results of the research, two themes were formed: "the relationship of the supervisory guideline to legal documents" and "the relationship of the supervisory guideline to the literature". Four categories emerged from these themes: "consistency of the supervisory guideline with the legal documents", "inconsistency of the supervisory guideline with legal documents", "consistency of the supervisory guideline with the literature", and "inconsistency of the supervisory guideline with the literature". It could be said that the guide is half-consistent or inconsistent on the basis of the legal documents. Under the category "inconsistency of the supervisory guideline with the legal documents", codes such as "outdated or repealed according to legal document", "legal document uncertainty", "legal gap", "insufficient referred to relevant legal bases", incomplete expression according to the legal document" were identified. In addition, the guideline was found to be in line with the literature in general. The codes "lack of content", "non-attribution", "inconsistency of concept" and "inconsistency" were identified within the scope of the "inconsistency of the audit guide with the literature " category. Practitioners may be suggested to benefit from the contributions of the research. Researchers may be advised to conduct research in qualitative, quantitative or mixed research design that will give scientific qualification to the supervisory guideline of private student dormitories.
\end{abstract}

Keywords: Educational supervision, Supervison Guideline, Dormitory supervision, Private Student Dormitories

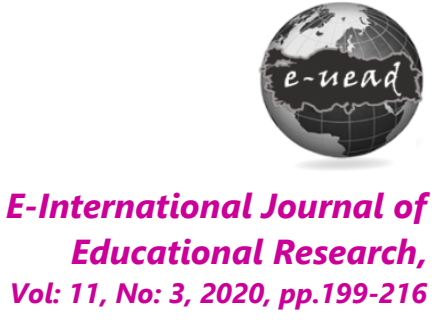

DOI: 10.19160/ijer.817509

\section{Suggested Citation:}

Toprakçı, E. \&. Özerten, K.N. (2020). The Examination of the Supervisory Guideline of Private Student Dormitories Based on Legal Documents and the Literature , E-International Journal of Educational Research, Vol: 11, No: 3, 2020, pp. 199-216, DOI: 10.19160/ijer.817509 


\section{EXTENDED ABSTRACT}

Problem: Monitoring processes in institutions providing Private Student Hosting Services, identification and prevention of obstacles in achieving the objectives, an affirmative way of working towards continuous improvement is possible with education supervision. There are 4560 private student dormitories which are subject to supervision and the services of the Ministry of National Education (MONE, 2018). The control, situation determination, evaluation and development processes are based on certain standards and traceability with the "The Supervisory Guideline of Private Student Dormitories" established by the Board of inspectors. It can be said that this guide draws a road map for the supervisors, the managers and related persons in these institutions and gives information on which subjects to be audited (Resmi Gazete, 2017-b). In addition, it can be considered that the guidance, based on legislation and up-to-date with the changing legislation, qualifies as user-friendly and allows the persons concerned to carry out the process with the least deficiency and error in the supervision. The laws of the Social Sciences, as we understand it, must be "laws" that regulate relationships between individuals, societies and people. That is, if the assemblies governing the countries or those concerned form the laws (legal documents) they will issue based on the information produced by social science, then social science will have "laws" like natural sciences (Toprakçl, 2017). It is clear that the preparation of the guide in the light of the scientific data revealed by the science of educational supervision is an important indicator in increasing the validity of the guide. In addition, it is thought that the guide can be effective with its scientific qualification in preventing the 'misconception 'of the concepts of supervision by practitioners in auditing activities. In the literature on Educational Supervision, there is no study on the supervision of private student accommodation services and no study on the "The Supervisory Guideline of Private Student Dormitories". It is thought that examining the coherent and inconsistent aspects of the guideline on the basis of the legal documents and literature is very important in terms of both guiding the practitioners and eliminating this deficiency in the literature. The purpose of this research is to examination of the Supervisory Guideline of Private Student Dormitorieson the basis of the legal documents and literature.

Method: In this research, a qualitative research-based document review method was used. The data were obtained using the qualitative research based document examination technique. Document review is expressed in two ways in the research as the general approach or data collection technique used in the realization of the purpose of the research. Public documents can be considered as indicators of events or processes of institutions. For this purpose, the "Privatel student dormitory guidance and supervision guideline" (2016), which is part of the MoNe Board of inspection, has been examined with the document review method. The Inspection Board published 16 supervisory guidelines prepared for various institutions in 2016. The document examined in this study is one of the published ones and entitled, "Private student dormitory guidance and supervision guide". Data in the research was analyzed with content analysis. Categorical analysis of content analysis types was used in the research. Categorical analysis is generally the division of a given message into units (codes) first, and then the grouping of those codes into categories. Category creation is the stage of creating a general result based on custom data (Miles \&Huberman, 2016). In this analysis, the data may not necessarily need to be quantified, but the data can also be given through percentage distribution or digitization. The internal validity (credibility) of the data was ensured by expert review and colleague confirmation. For this purpose, the researchers, who examined the supervisory guidelines of different institutions, came together on a specific day and time every week via live meeting tools on the internet. The researchers analysed the content of the guidelines they examined, created codes and themes and focused on their similar and different aspects. Also, an academic and an inspector took part in these meetings to offer their opinions and gave feedback on the activities during the meetings. Besides, the raw data of the research was stored for external reliability (confirmability). 
Findings: The guideline was related to literature and laws. This relationship was half-consistent or inconsistent based on laws categorie. In addition, the guideline was found to be in line with the literature in general. Some of the legal documents referred to were not up-to-date or were repealed. Besides, there was no reference to the related legal document or some references were missing in some of the statements. Besides, some of the statements were incomplete, undefined or less detailed according to the legal document. Some statements had no legal basis since the legal document was repealed and a new one was not prepared. Besides, there were deficiencies in the content of some statements according to the literature. None of the statements was referred to scientific studies. The use of some of the concepts was inconsistent with the literature or some concepts covered each other. Finally, some expressions contradicted the literature and had to be corrected.

Suggestions: Researchers can present model recommendations in the creation of supervisory guidelines on the basis of the literature and the legal documents. In-service training programs can be organized for education inspectors on the basis of scientific research. Studies may be carried out by researchers to ensure that the relevant items amended on the basis of the updated legal documents are included in the supervisory guide in connection with digital chain blocks (e.g. links or with $Q R$ codes). In the preparation phase of the supervision guide, the involvement of academics, experts, or providing them with the opportunities to examine and present their opinions can be effective in ensuring consistency in terms of the literature. Practitioners may be offered to establish a unit for the preparation and updating of guidelines. 